\title{
METODE PENERJEMAHAN NON - EQUIVALENT WORD LEVEL STUDI KASUS MENTERJEMAHKAN NOVEL PRINCESS DIARIES KARYA MEG CABOT
}

\author{
Yulianti $^{1}$, Dendi Suhendi ${ }^{2}$, Feny Putri Maharany ${ }^{3}$ \\ AKPAR Citra Buana Indonesia \\ akpar@gmail.com
}

\begin{abstract}
The purpose of the study is to know The Strategy in Translating Non-Equivalent Word Levels in the Novel of "The Princess Diaries", written by Meg Cabot. Sample of the research is taken from both English and Indonesian Novel version. The research methodology that is used Descriptive Qualitative Method and the technique of data analysis that is used is a descriptive-documentation method. The researches finding are: 1). There are some translation strategies dealing with problems of non-equivalent word level by Mona Baker are used in translating the novel; Translation by using a loan word or loan word plus explanation is used 61 times, translation by paraphrase using a related word is used 22 times, translation by paraphrase using unrelated word is used 25 times, translation by omission is used 7 times, and translation by cultural substitution is used 13 times. 2). There is the dominant type in translating the novel of The Princess Diaries, and The loan word or loan word plus explanations is the dominant type in translating the novel. It has the highest data about 47 , $66 \%$. These strategies are also used in to make the result of translation not only enjoyable but also meaningful for the readers.
\end{abstract}

Keyword: Translating, Non-Equivalent Word Levels, Strategy, Novel

\begin{abstract}
Abstrak - Tujuan penelitian ini adalah untuk mengetahui strategi penerjemahan pada tingkatan kata yang tidak ada padanannya dalam novel "The Princess Diaries" karya Meg Cabot. Sample yang digunakan dalam penelitian ini adalah sebuah novel dengan menggunakan kedua versi baik Indonesia maupun Inggris. Metode yang digunakan adalah deskriptif kualitatif dan menggunakan teknik dokumentasi deskriptif. Terdapat dua hal dalam penelitian ini, yaitu: 1. Terdapatnya lima strategi penerjemahan pada tingkatan kata yg tidak ada padanannya dalam novel "The Princess Diaries" dengan merujuk kepada teori Mona Baker; Strategi dengan menggunakan kata pinjaman, Strategi dengan menggunakan prasa yang berhubungan, Strategi dengan menggunakan prasa yang tidak berhubungan, Strategi yang menggunakan penghilangan kata, dan Startegi yang menggunakan subtitusi budaya. 2. Terdapatnya strategi yang paling dominan digunakan oleh pengarang dalam novel "The Princess Diaries" yakni strategi menggunakan kata pinjaman, terdapat 61 data atau sebanyak 47,66 $\%$ berupa kata maupun prasa. Diharapkan startegi yang digunakan dalam penelitian ini mampu menghasilkan penerjemahan yang bermakna dan mudah dipahami pembaca.
\end{abstract}

Kata kunci: Penerjemahan, Tingkatan Kata yang Tidak ada Padananya, Strategi, Novel

\section{PENDAHULUAN}

Bahasa memiliki peran penting dalam kehidupan bermasyarakat, karena bahasa diperlukan dalam mengkomunikasikan dan menyampaikan gagasan satu dengan lainnya. Bahasa adalah suatu sistem komunikasi dalam pidato dan tulisan yang digunakan oleh masyarakat suatu negara tertentu (A.S Hornby: 2000: .29).
Seiring dengan kemajuan teknologi dan ilmu pengetahuan, buku dan artikel telah ditulis oleh para ahli di segala bidang. Publik membutuhkan buku-buku itu tetapi tidak semuanya mampu memahami buku tersebut, yang ditulis dalam bahasa yang tidak mereka ketahui. Itulah salah satu alasan mengapa kita membutuhkan terjemahan. 
Berdasarkan Oxford Advanced Learners 'Dictionary, terjemahan berarti kegiatan menerjemahkan. Studi penerjemahan ditujukan pada pengamatan proses transfer yang berorientasi pada fakta-fakta, dengan demikian menciptakan prasyarat untuk membangun kerangka acuan berbasis linguistik dan psiko linguistik, empiris, deskriptif, dan eksplanatif (Eppert), 1982: 175).

Penerjemahan sangat penting dalam mentransmisikan budaya, menurut Peter New mark "Translation is rendering the meaning of a text into another language in the way that the author intended the text", maksudnya terjemahan adalah menerjemahkan makna dari suatu teks ke dalam bahasa lain sesuai dengan maksud penulisnya."

Penerjemahan mempelajari bentuk leksikon, struktur tata bahasa, situasi komunikasi, dan konteks budaya dari teks bahasa sumber, kemudian menganalisisnya untuk menentukan maknanya, kemudian merekonstruksi makna yang serupa dengan menggunakan struktur leksikon dan tata bahasa yang sesuai dengan bahasa reseptor dan konteks budayanya (Larson: 1998: .3). Dari pernyataan di atas, jelaslah bahwa terjemahan terdiri dari makna, struktur bahasa, konteks budaya, dan kesepadanan. "A translator requires knowledge of literary and non-literary textual criticism, since he has to assess the quality of a text, before he decides how to interpret and then translated it", bahwa seorang penerjemah membutuhkan pengetahuan tentang kritik sastra dan non-sastra, karena ia harus menilai kualitas suatu teks, sebelum memutuskan bagaimana menafsirkan dan kemudian menerjemahkannya" (Peter Newmark: 1982: 55).
Seringkali kita menemukan beberapa "kata" dalam karya sastra seperti novel, khususnya teen-lit (novel bagi kaum remaja) memiliki arti tersendiri. Dengan demikian, sebuah kata dalam Bahasa Sumber (BS) yang tidak memiliki kata perumpamaan dalam bahasa target (BT) dapat menyebabkan masalah ketidaksepadanan dalam tingkatan kata. Menurut Mona Baker "non- equivalence for a word which occurs in the source text”. Dalam sebuah paragraph/teks sering ditemukan kata yang tidak memiliki padananya.

Oleh karena itu, seorang penerjemah harus memilih metode penerjemahan untuk mengatasi masalah tersebut. Penggunaan metode yang tepat akan menentukan kredibilitas penerjemah di mata para reader. Pilihan padanan yang cocok akan selalu bergantung tidak hanya pada sistem linguistik yang ditangani oleh penerjemah, tetapi juga tergantung pada cara penulis sumber bahasa teks dan produser target teks (Mona Baker: 1995: .18).

Berdasarkan temuan di atas penulis tertarik untuk melakukan penelitian akan adanya non-equivalent word dan strategi untuk mengatasinya. Dengan mengambil salah satu Novel Karya Meg Cabot "The Princess Diaries", adalah The Teen-lit terlaris New York Times, dan telah dibuat menjadi film Disney yang sangat populer dengan judul yang sama.

Kualitas terjemahan sangat bergantung pada pengetahuan, kepiawaian, pendidikan, latar belakang budaya, keahlian dan bahkan suasana hati penerjemah. Kebutuhan akan pengembangan metodologi untuk meningkatkan proses transfer yang efektif dan efisien dari satu bahasa ke bahasa lain (Newmark, 1991).

Teori terjemahan yang paling terkenal seperti Delishe (2980), Newmark (1988), 
Nida (1969), Nord (1994), dan Kusmaul (1995), sepakat bahwa aspek pertama adalah pemahaman. dan interpretasi teks dengan mempertimbangkan tingkat tekstual, referensial, kohesi, dan tingkat kealamiannya. Kompetensi ini meliputi pemahaman bacaan dan interpretasi pesan (encoding dan decoding). Aspek kedua adalah penerapan berbagai strategi dalam memilih metode, teknik, dan prosedur yang sesuai. Seorang penerjemah dapat menggunakan transfer, budaya setara fungsional, sinonim, transposisi, modulasi, kompensasi, pengurangan, dan perluasan atau amplifikasi untuk mengembalikan ide yang terkandung dalam unit terjemahan (Newmark, 1991). Masyarakat tertarik dengan karya sastra yang mampu menghibur mereka. Contoh karya sastra bentuk ini adalah novel. Jika kita membandingkan terjemahan sebuah novel (dari Bahasa Sumber/BS ke Bahasa Target/BT) kita dapat menemukan beberapa yang tidak setara dalam sebuah kata, frase atau klausa. Non-equivalent ini terjadi karena kata dalam BS terkadang tidak dapat ditemukan di BT. Oleh karena itu, penerjemah akan menggunakan beberapa strategi untuk menyelesaikannya dan juga akan menerapkan strategi yang paling banyak digunakan dalam menerjemahkan kasus-kasus tersebut.

\section{METODE PENELITIAN}

Penelitian ini menggunakan metode deskriptif kualitatif. Menurut Sowel dan Casey (1982), jenis penelitian ini menggunakan data yang sudah tersedia dalam pengumpulan data, dan tidak memerlukan manipulasi variabel. Lebih lanjut Nazir (1999: 63) menyatakan bahwa metode deskriptif adalah suatu metode untuk menganalisis status suatu kelompok masyarakat, suatu objek, sekumpulan kondisi, sistem pemikiran, atau urutan kejadian pada waktu sekarang. Selain itu, Strauss dan Corbin (1990: 19) mendefinisikan penelitian kualitatif, sebagai jenis penelitian apa pun yang menghasilkan temuan yang tidak diperoleh melalui prosedur statistik atau cara kuantifikasi lainnya.

\section{A. Teknik Pengumpulan Data}

Penelitian ini menggunakan metode deskriptif dan dokumentasi dengan mengumpulkan teks bahasa sumber dan teks bahasa sasaran. Data yang terkumpul dianalisis secara kualitatif berdasarkan teori strategi penerjemahan Mona Baker. Dalam analisis ini menjelaskan apakah terjemahan menyebabkan perubahan makna, dapat dimengerti, sesuai dengan kaidah bahasa sasaran, dan menyimpang dari teori yang berlaku atau tidak. Menurut Arikunto (1990: 321) studi dokumen adalah dengan cara mendapatkan data tentang kasus atau variabel melalui catatan, transkrip, buku, majalah, dll.

\section{B. Teknik Analisis Data}

Teknik pengambilan data dalam penelitian ini dengan cara mengumpulkan kedua versi novel yang berjudul "The Princess Diaries" dan "The Princess Diaries" Buku Harian Sang Putri". Peneliti akan memilih (seratus dua puluh delapan) 128 data representatif dari novel "The Princess Diaries". Data yang diperoleh berupa kata atau frase. Hal ini sejalan dengan Fraenkel dan Wallen "Jumlah subjek minimal yang direkomendasikan adalah 100 subjek untuk studi deskriptif, 50 studi korelasi, dan 30 subjek di setiap kelompok untuk studi comparative kausal dan eksperimental (1993, P. 97). Setelah itu, peneliti akan menganalisis data untuk mengetahui masalah yang terjadi dan strategi apa yang digunakan oleh Donna Widjajanto untuk mengatasi masalah tersebut berdasarkan strategi yang 
dikemukakan oleh Mona Baker (1995, P. 26).

\section{HASIL DAN PEMBAHASAN}

Peneliti mengambil lima strategi penerjemahan untuk menganalisis data dalam menerjemahkannya, yaitu terjemahan dengan menggunakan kata pinjaman atau kata pinjaman ditambah penjelasan, substitusi budaya, omission (penghilangan kata), terjemahan dengan parafrase menggunakan kata terkait, terjemahan dengan parafrase menggunakan kata-kata yang tidak terkait.

1) Terjemahaan menggunakan loan word or loan word plus explanation (terjemahan menggunakan kata pinjaman atau kata pinjaman plus penjelasan).

Dalam penerjemahan kata serapan, satu item mungkin tidak ditemukan dalam bahasa tertentu karena bergantung pada budaya lingkungan.

Tabel 4.1 Translation using loan word or loan word plus explanation

\begin{tabular}{|c|c|c|c|}
\hline \multirow{2}{*}{$\begin{array}{l}\mathrm{N} \\
\mathrm{O}\end{array}$} & $\begin{array}{l}\text { Pag } \\
\text { es }\end{array}$ & \multirow{2}{*}{$\begin{array}{c}\text { Original } \\
\text { word/phr } \\
\text { ase }\end{array}$} & \multirow{2}{*}{ Translation } \\
\hline & $\begin{array}{l}\text { SL/ } \\
\text { TL }\end{array}$ & & \\
\hline 1 & $\begin{array}{l}2 / 1 \\
2 \\
\end{array}$ & Hey & Hai \\
\hline 2 & $\begin{array}{l}2 / 1 \\
2\end{array}$ & Privacy & Privasi \\
\hline 3 & $\begin{array}{l}2 / 1 \\
2 \\
\end{array}$ & Cologne & Cologne \\
\hline 4 & $\begin{array}{l}2 / 1 \\
2 \\
\end{array}$ & Familiar & Familier \\
\hline 5 & $\begin{array}{l}2 / 1 \\
2\end{array}$ & Sensitive & Sensitif \\
\hline 6 & $\begin{array}{l}2 / 1 \\
2 \\
\end{array}$ & Overactive & Overaktif \\
\hline
\end{tabular}

\begin{tabular}{|l|l|l|l|} 
& $2 / 1$ & & \\
7 & 2 & Popular & Populer \\
\hline & $2 / 1$ & & \\
8 & 3 & Assertive & Asertif \\
\hline & $2 / 1$ & & \\
9 & 3 & Pasta & Pasta \\
\hline 1 & $3 / 1$ & Vegetaria & \\
0 & 3 & n & Vegetarian \\
\hline 1 & $4 / 1$ & & \\
1 & 5 & Perfume & Parfum \\
\hline 1 & $4 / 1$ & & \\
2 & 6 & Model & Model \\
\hline 1 & $4 / 1$ & & \\
3 & 6 & Dumpling & Dumpling \\
\hline 1 & $4 / 1$ & & \\
4 & 6 & Boggle & Boggle \\
\hline 1 & $4 / 1$ & Displacem & \\
5 & 6 & ent & Displacement \\
\hline 1 & $4 / 1$ & & \\
6 & 9 & Sarcastic & Sarkastik \\
\hline 1 & $4 / 1$ & & \\
7 & 6 & Snapple & Snapple \\
\hline 1 & $5 / 1$ & & \\
8 & 7 & Period & Period \\
\hline 1 & $5 / 1$ & & \\
9 & 7 & On-line & On-line \\
\hline 2 & $5 / 1$ & Crack- & \\
0 & 7 & head & Crack-head \\
\hline 2 & $7 / 2$ & & \\
1 & 3 & Studio & Studio \\
\hline 2 & $8 / 2$ & & \\
2 & 4 & Well & Well \\
\hline 2 & $9 / 2$ & Cultural- & \\
3 & 5 & diversity & Cultural-diversity \\
\hline 2 & $9 / 2$ & A & \\
4 & 5 & strapless & Strapless \\
\hline 2 & $10 /$ & & \\
5 & 29 & Proposal & Proposal \\
\hline 2 & $12 /$ & & \\
6 & 31 & Chateau & Chateau \\
\hline 2 & $12 /$ & & \\
7 & 32 & Sidecar & Sidecar \\
\hline 2 & $21 /$ & & \\
8 & 32 & Toilet & Toilet \\
\hline 2 & $13 /$ & & \\
9 & 34 & Band aids & Band-aid \\
\hline 3 & $13 /$ & & \\
0 & 35 & C-Cup & Cup-C \\
\hline 3 & $19 /$ & & \\
1 & 47 & Incident & Incident \\
\hline & & & \\
\hline
\end{tabular}




\begin{tabular}{|c|c|c|c|}
\hline $\begin{array}{l}3 \\
2\end{array}$ & $\begin{array}{l}24 / \\
55\end{array}$ & Gallery & Gallery \\
\hline $\begin{array}{l}3 \\
3\end{array}$ & $\begin{array}{l}25 / \\
57\end{array}$ & $\begin{array}{l}\text { A yield } \\
\text { sign }\end{array}$ & Tanda Yield \\
\hline $\begin{array}{l}3 \\
4\end{array}$ & $\begin{array}{l}27 / \\
61\end{array}$ & Fair & Fair \\
\hline $\begin{array}{l}3 \\
5\end{array}$ & $\begin{array}{l}27 / \\
61\end{array}$ & Make-up & Make-up \\
\hline $\begin{array}{l}3 \\
6 \\
\end{array}$ & $\begin{array}{l}30 / \\
66\end{array}$ & $\begin{array}{l}\text { French } \\
\text { toast }\end{array}$ & $\begin{array}{l}\text { French toast / roti } \\
\text { bakar }\end{array}$ \\
\hline $\begin{array}{l}3 \\
7\end{array}$ & $\begin{array}{l}30 / \\
66\end{array}$ & Favorite & Favorite \\
\hline $\begin{array}{l}3 \\
8\end{array}$ & $\begin{array}{l}33 / \\
70\end{array}$ & Ozone & Ozone \\
\hline $\begin{array}{l}3 \\
9 \\
\end{array}$ & $\begin{array}{l}35 / \\
72\end{array}$ & $\begin{array}{l}\text { Walkie } \\
\text { talkie }\end{array}$ & Walkie talkie \\
\hline $\begin{array}{l}4 \\
0\end{array}$ & $\begin{array}{l}38 / \\
79\end{array}$ & A fetishist & \begin{tabular}{lr}
\multicolumn{1}{l}{ Fetishist- } & \\
orang yang & \\
senang & memuja \\
beberapa & benda \\
tertentu & \\
\end{tabular} \\
\hline $\begin{array}{l}4 \\
1 \\
\end{array}$ & $\begin{array}{l}38 / \\
79 \\
\end{array}$ & Lobby & Lobby \\
\hline $\begin{array}{l}4 \\
2 \\
\end{array}$ & $\begin{array}{l}40 / \\
82\end{array}$ & $\begin{array}{l}\text { Vacuum } \\
\text { cleaner }\end{array}$ & Vacuum cleaner \\
\hline $\begin{array}{l}4 \\
3 \\
\end{array}$ & $\begin{array}{l}41 / \\
83\end{array}$ & Plus & Plus \\
\hline $\begin{array}{l}4 \\
4 \\
\end{array}$ & $\begin{array}{l}41 / \\
83\end{array}$ & Popcorn & Popcorn \\
\hline $\begin{array}{l}4 \\
5 \\
\end{array}$ & $\begin{array}{l}43 / \\
85\end{array}$ & Eyeliner & Eyeliner \\
\hline $\begin{array}{l}4 \\
6\end{array}$ & $\begin{array}{l}60 / \\
117\end{array}$ & $\begin{array}{l}\text { A brief } \\
\text { manic } \\
\text { phrase }\end{array}$ & $\begin{array}{l}\text { Periode } \\
\text { manic singkat }\end{array}$ \\
\hline $\begin{array}{l}4 \\
7 \\
\end{array}$ & $\begin{array}{l}62 / \\
121 \\
\end{array}$ & Shock & Shock \\
\hline $\begin{array}{l}4 \\
8 \\
\end{array}$ & $\begin{array}{l}78 / \\
144 \\
\end{array}$ & Lipstick & Lipstick \\
\hline $\begin{array}{l}4 \\
9 \\
\end{array}$ & $\begin{array}{l}80 / \\
147\end{array}$ & Fashion & Fashion \\
\hline $\begin{array}{l}5 \\
0\end{array}$ & $\begin{array}{l}81 / \\
148\end{array}$ & Blow & Blow \\
\hline $\begin{array}{l}5 \\
1\end{array}$ & $\begin{array}{l}83 / \\
150\end{array}$ & Surfing & Surfing \\
\hline $\begin{array}{l}5 \\
2 \\
\end{array}$ & $\begin{array}{l}88 / \\
158\end{array}$ & $\begin{array}{l}\text { Remote } \\
\text { control }\end{array}$ & $\begin{array}{l}\text { Remote } \\
\text { control }\end{array}$ \\
\hline $\begin{array}{l}5 \\
3\end{array}$ & $\begin{array}{l}127 \\
/ 29 \\
1\end{array}$ & Idiot & Idiot \\
\hline $\begin{array}{l}5 \\
4\end{array}$ & $\begin{array}{l}130 \\
/ 29 \\
6\end{array}$ & Sociopath & Sosiopat \\
\hline
\end{tabular}

\begin{tabular}{|l|l|l|l|} 
& 130 & & \\
5 & $/ 29$ & & \\
5 & 7 & Close-up & Close-up \\
\hline & 134 & & \\
5 & $/ 30$ & & \\
6 & 6 & Ivory & Ivory \\
\hline & 132 & & \\
5 & $/ 30$ & Slow & \\
7 & 7 & dance & Slow dance \\
\hline & 182 & & \\
5 & $/ 30$ & Supportiv & \\
8 & 7 & e & Supportive \\
\hline & 182 & & \\
5 & $/ 30$ & Even- & Even- \\
9 & 4 & organizer & Organizer \\
\hline & 183 & & \\
6 & $/ 30$ & & \\
0 & 8 & High five & High five \\
\hline & 205 & & \\
6 & $/ 22$ & A phallic & A phallic \\
1 & 8 & symbol & Symbol \\
\hline
\end{tabular}

Istilah dumpling dan displacement diterjemahkan menjadi "kue bola/pangsit," dan gejala psikologi," dalam kamus Oxford. Hal ini terkait dengan budaya masyarakat dalam cerita yang menganggap tepung sebagai makanan pokok mereka. Padahal makanan pokok di Indonesia adalah nasi. Jadi kata tersebut tak tergantikan. Pangsit dikategorikan ke dalam item khusus budaya. Sedangkan displacement merupakan salah satu istilah gejala dalam psikologi, dan dianggap sebagai konsep modern yang memiliki arti tersendiri.

Istilah Boggle dan Snapple tidak ditemukan dalam bahasa Indonesia. Dari kalimat "Lily dan saya hanya dudukduduk saja bermain Boggle" (hal.8) dan "ketika Lily dan aku sedang asyik bermain Boggle" (hal.16), terlihat jelas bahwa Boggle adalah salah satu jenis permainan yang dimainkan oleh2 orang atau lebih. Snapple tidak bisa diterjemahkan sebagai salah satu jenis makanan. Kedua istilah ini tidak ada padanannya dalam bahasa Indonesia; tidak ada substitusi budaya 
yang cocok untuk kata tersebut. Strategi penerjemahan kata serapan (loan word) diterapkan untuk mengatasi masalah tersebut.

On line dapat diterima hampir dalam semua bahasa. On line di identifikasikan sebagai istilah komputer. Sebagai suatu konsep modern yang telah diakui, on line berarti dikendalikan atau dihubungkan ke komputer atau ke internet (A.S Hornby: 2000) maka strategi kata pinjaman dipilih dalam terjemahan ini. Lebih lanjut, menurut Mona Beker, (1995: 34) strategi kata pinjaman sangat umum dalam jenis kata non-equivalent ini.

Selain itu istilah strapless juga dikenal di Indonesia. Ini adalah jenis pakaian tanpa tali di bagian bahu. Namun istilah-istilah tersebut tidak memiliki padanan yang tepat dalam bahasa Indonesia. Karena istilah tersebut sudah tidak asing lagi maka strategi penerjemahan menggunakan kata pinjaman untuk dapat dengan mudah dipahami dalam bahasa target tanpa penjelasan tambahan lainnya.

Istilah chateau tidak dikenal dalam budaya Indonesia. Ini awalnya ada di Prancis di mana istilah itu pada dasarnya diformulasikan. Chateau berarti kastil atau rumah pedesaan besar di Prancis. Karena Chateau memiliki konsep sendiri, maka strategi penerjemahan kata pinjaman dipilih. Penerjemah menggunakan istilah chateau dalam bahasa target karena istilah tersebut telah menghadirkan konsepnya sendiri.

Istilah band-aids cukup familiar di Indonesia. Itu adalah plester untuk menutupi bagian tubuh biasanya kulit yang terluka. Alhasil, diterapkan strategi penerjemahan menggunakan kata pinjaman.

Masalah yang berbeda terjadi pada kata Yield sign yang tidak dikenal dalam bahasa Indonesia. Namun ternyata itu adalah simbol untuk merepresentasikan sesuatu yang tidak dileksikalisasikan dalam bahasa Indonesia. Dengan demikian, penerjemah menyimpan kata tersebut dalam bahasa target dengan menggunakan strategi penerjemahan dengan menggunakan kata pinjaman. Terlebih lagi, meski istilah tersebut tidak dijelaskan, namun bentuknya secara implisit dijelaskan dalam kalimat tersebut. Jadi, pembaca bahasa target bisa mendapatkan pesan tersebut

Istilah roti panggang Perancis adalah istilah roti panggang yang tidak ada dalam bahasa target. Untuk itu diterapkan strategi penerjemahan kata pinjaman plus penjelasan. Donna menggunakan france toast dalam bahasa target plus informasi, dengan kata yang lebih umum dalam bahasa target yaitu roti bakar. Istilah fetishist adalah istilah khusus seseorang yang suka bekerja mengirimkan hal-hal tertentu. Namun karena bahasa Indonesia tidak memiliki padanan istilah tersebut, maka digunakan strategi penerjemahan dengan menggunakan kata serapan plus penjelasan. Penerjemah menyimpan istilah tersebut dalam bahasa target dan menambahkannya dengan penjelasan, yaitu fetishist-orang yang senang memuja beberapa benda tertentu, agar pembaca bahasa target dapat memahami istilah tersebut.

\section{2) Terjemahan menggunakan paraphrases using a related word}

Strategi ini digunakan ketika menerjemahkan kata atau prase sesuai dengan sumber bahasa, tetapi dalam bentuk target bahasa berbeda, ketika frekuensi penggunaan bentuk tertentu dalam teks sumber secara signifikan lebih tinggi daripada target bahasa. Berikut adalah beberapa contoh penggunaan strategi dengan menggunakan paraphrase dengan kata yang berkaitan. 
Table 4.2 Strategy Paraphrases Using Related Word

\begin{tabular}{|c|c|c|c|}
\hline \multirow{2}{*}{$\begin{array}{l}\mathrm{N} \\
\mathrm{O}\end{array}$} & $\begin{array}{l}\text { Pag } \\
\text { es }\end{array}$ & \multirow{2}{*}{$\begin{array}{l}\text { Original } \\
\text { words/ } \\
\text { Phrases }\end{array}$} & \multirow{2}{*}{ Translation } \\
\hline & $\begin{array}{l}\text { SL/ } \\
\text { TL }\end{array}$ & & \\
\hline 1 & $\begin{array}{l}4 / 1 \\
3 \\
\end{array}$ & $\begin{array}{l}\text { A lowly } \\
\text { freshman }\end{array}$ & $\begin{array}{l}\text { Si anak yang satu } \\
\text { yang } \\
\text { berharga }\end{array}$ \\
\hline 2 & $\begin{array}{l}6 / 1 \\
4 \\
\end{array}$ & Cat litter & $\begin{array}{ll}\text { Pasir } & \text { unntuk } \\
\text { tempat } & \text { kotoran } \\
\text { kucing } & \\
\end{array}$ \\
\hline 3 & $\begin{array}{l}9 / 1 \\
7 \\
\end{array}$ & $\begin{array}{l}\text { Gifted and } \\
\text { talented } \\
\text { class }\end{array}$ & $\begin{array}{l}\text { Kelas anak } \\
\text { berbakat }\end{array}$ \\
\hline 3 & $\begin{array}{l}9 / 1 \\
7\end{array}$ & $\begin{array}{l}\text { Gifted and } \\
\text { talented } \\
\text { class }\end{array}$ & $\begin{array}{l}\text { Kelas anak } \\
\text { berbakat }\end{array}$ \\
\hline 4 & $\begin{array}{l}11 / \\
12 \\
\end{array}$ & $\begin{array}{l}\text { Major } \\
\text { holidays }\end{array}$ & $\begin{array}{l}\text { Hari-hari libur } \\
\text { nasional }\end{array}$ \\
\hline 5 & $\begin{array}{l}18 / \\
27\end{array}$ & Type casting & $\begin{array}{l}\text { Pemilihan pemain } \\
\text { yang sangat } \\
\text { tipikal }\end{array}$ \\
\hline 6 & $\begin{array}{l}29 / \\
41 \\
\end{array}$ & $\begin{array}{l}\text { A house } \\
\text { phone }\end{array}$ & Telepon di bawah \\
\hline 7 & $\begin{array}{l}40 / \\
52 \\
\end{array}$ & Fact sheets & $\begin{array}{l}\text { Laporan tentang } \\
\text { berbagai Negara }\end{array}$ \\
\hline 8 & $\begin{array}{l}40 / \\
53 \\
\end{array}$ & $\begin{array}{l}\text { Snowcapped } \\
\text { Alps }\end{array}$ & $\begin{array}{l}\text { Pegunungan } \\
\text { Alpen yang } \\
\text { puncaknya } \\
\text { selalu tertutup } \\
\text { salju }\end{array}$ \\
\hline 9 & $\begin{array}{l}63 / \\
79 \\
\end{array}$ & Stalker & $\begin{array}{l}\text { Orang yang } \\
\text { senang menguntit }\end{array}$ \\
\hline $\begin{array}{l}1 \\
0\end{array}$ & $\begin{array}{l}68 / \\
84\end{array}$ & $\begin{array}{l}\text { The Pulpy } \\
\text { kind }\end{array}$ & $\begin{array}{ll}\text { Jus yang } & \text { masih } \\
\text { ada } & \text { daging } \\
\text { buahnya } & \\
\end{array}$ \\
\hline $\begin{array}{l}1 \\
1\end{array}$ & $\begin{array}{l}105 \\
/ 12 \\
4 \\
\end{array}$ & $\begin{array}{l}\text { Princess } \\
\text { material }\end{array}$ & $\begin{array}{l}\text { Cocok menjadi } \\
\text { putri }\end{array}$ \\
\hline $\begin{array}{l}1 \\
2\end{array}$ & $\begin{array}{l}110 \\
/ 13 \\
0\end{array}$ & $\begin{array}{l}\text { Orally } \\
\text { fixated }\end{array}$ & $\begin{array}{l}\text { Telat dalam } \\
\text { perkembangan } \\
\text { fase oral }\end{array}$ \\
\hline $\begin{array}{l}1 \\
3 \\
\end{array}$ & $\begin{array}{l}117 \\
/ 13 \\
7 \\
\end{array}$ & $\begin{array}{l}\text { Iconoclastic } \\
\text { sense of } \\
\text { style }\end{array}$ & $\begin{array}{ll}\text { Gayanya yang } \\
\text { mondobrak }\end{array}$ \\
\hline
\end{tabular}

\begin{tabular}{|c|c|c|c|}
\hline 1 & $\begin{array}{l}126 \\
/ 14 \\
6\end{array}$ & $\begin{array}{l}\text { Be off my } \\
\text { back }\end{array}$ & $\begin{array}{l}\text { Tidak akan } \\
\text { merepotkanku }\end{array}$ \\
\hline $\begin{array}{l}1 \\
5\end{array}$ & $\begin{array}{l}129 \\
/ 15 \\
0\end{array}$ & $\begin{array}{l}\text { A human Q- } \\
\text { type }\end{array}$ & $\begin{array}{l}\text { Orang yang benar- } \\
\text { benar asing }\end{array}$ \\
\hline $\begin{array}{l}1 \\
6\end{array}$ & $\begin{array}{l}150 \\
/ 17 \\
1\end{array}$ & A republican & $\begin{array}{l}\text { Pendukung partai } \\
\text { republic }\end{array}$ \\
\hline $\begin{array}{l}1 \\
7\end{array}$ & $\begin{array}{l}161 \\
/ 18 \\
3\end{array}$ & A big whiner & $\begin{array}{l}\text { Senang sekali } \\
\text { berkeluh kesah }\end{array}$ \\
\hline $\begin{array}{l}1 \\
8\end{array}$ & $\begin{array}{l}182 \\
/ 20 \\
4\end{array}$ & $\begin{array}{l}\text { Hyperventila } \\
\text { ting }\end{array}$ & $\begin{array}{l}\text { Bisa mulai } \\
\text { bernafas lagi }\end{array}$ \\
\hline $\begin{array}{l}1 \\
9\end{array}$ & $\begin{array}{l}212 \\
/ 23 \\
6\end{array}$ & $\begin{array}{l}\text { Disney } \\
\text { fication }\end{array}$ & Keracunan Disney \\
\hline $\begin{array}{l}2 \\
0\end{array}$ & $\begin{array}{l}257 \\
/ 28 \\
4\end{array}$ & $\begin{array}{l}\text { Class } \\
\text { valedictoria } \\
\mathrm{n}\end{array}$ & $\begin{array}{l}\text { Murid terpandai } \\
\text { yang akan } \\
\text { membaakan } \\
\text { pidato wisuda } \\
\text { angkatannya }\end{array}$ \\
\hline $\begin{array}{l}2 \\
1\end{array}$ & $\begin{array}{l}20 / \\
30\end{array}$ & Literacy rate & $\begin{array}{l}\text { Tingkat buta } \\
\text { huruf }\end{array}$ \\
\hline $\begin{array}{l}2 \\
2\end{array}$ & $\begin{array}{l}105 \\
/ 12 \\
4\end{array}$ & Mules & Sandal tanpa hak \\
\hline
\end{tabular}

Istilah Gifted and talented class (kelas anak berbakat), kata berbakat dalam bahasa Indonesia diterjemahkan ke dalam kelas yang dikaruniai dan memiliki bakat, tentunya hal itu membuat perbedaan besar dalam makna kontekstual yang ingin dicapai dalam bahasa sumber, kelas berbakat dan berbakat di kelas tersebut. Dalam cerita ini sekolah yang dianggap memiliki bakat dan kelebihan. Oleh karena itu, strategi parafrase menggunakan kata terkait dipilih untuk menangani masalah tersebut. Donna Widjajanto menerjemahkan kelas berbakat menjadi kelas untuk anak-anak yang berbakat. Major Holiday adalah hari-hari saat tidak berada di tempat kerja atau sekolah. Dengan kata lain, hari-hari ketika bebas dari aktivitas formal. Dalam bahasa Indonesia disebut Hari-Hari Libur 
Nasional, istilah ini telah dileksikalisasi dalam bentuk yang berbeda.

Istilah type casting terbentuk dari kata type cast yang menandakan seorang aktor yang selalu diberi karakter yang sama dalam sebuah peran. Dalam bahasa Indonesia, ini diterjemahkan sebagai pemain yang memainkan peran dengan tipe tertentu (Echols and Shadily: 1996). Berdasarkan informasi tersebut terlihat jelas bahwa Donna memparafrasekan istilah tersebut menjadi pemilihan pemain yang sangat tipikal. Istilah house phone ditinjau dari teksnya, telepon rumah bukanlah telepon yang ada di dalam rumah atau dalam bahasa Indonesia telepon rumah. Sebaliknya, ini adalah telepon yang terletak di lantai pertama (lobi) hotel. Jadi, dalam bahasa Indonesia diartikan sebagai telepon yang diletakkan di lantai bawah. Penerjemah tidak menjelaskan di lantai bawah mana telepon itu ada, karena dijelaskan dalam kalimat sebelumnya bahwa dia berada di hotel mewah.

Berdasarkan Oxford Advance Learner's Dictionary (2000: 450), fact sheet adalah selembar kertas yang memberikan informasi tentang suatu subjek, khususnya (di Inggris) yang dibahas dalam program radio atau televisi. Dari cerita tersebut peneliti menemukan bahwa Mia memiliki tugas untuk menulis fact sheet pada setiap negara di Eropa pada saat kelas 7 SD dan ia memutuskan untuk menulis tentang Genovia. "Saya tahu ini karena saya harus membuat fact sheet tentang setiap negara di Eropa di kelas tujuh, dan Genovia ada di sana bersama Disneyland (hlm. 21). Dengan demikian, Donna Widjajanto memparafrasekan fact sheet menjadi laporan tentang berbagai negara.

Snowcapped Alps secara semantic adalah berselimut salju atau tertutup salju, yang artinya lebih besar dari frasa itu sendiri. Donna Widjajanto mengatakan
Snowcapped Alps menjadi Pegunungan Alpen yang puncaknya tertutup salju. Jadi, para pembaca bisa mendapatkan gambaran dari dekat tentang Snowcapped Alps yang jelas-jelas tidak ada di Indonesia. Stalker diterjemahkan menjadi orang yang senang menguntit. Sesuai dengan artinya dalam Oxford Advance Learner's Dictionary (2000: 1261) yaitu orang yang mengikuti dan mengawasi orang lain dalam jangka waktu yang lama dengan cara mengganggu atau menakutkan.

Terbatasnya akan istilah khusus dalam menerjemahkan pulpy kind. Pulpy memiliki kemiripan dengan mushy atau dalam bahasa Indonesia seperti bubur. Selain itu, kata pulpy berasal dari kata pulp yang artinya daging buah (Shadily dan Echols: 1992) sehingga penerjemah memparafrasekan kalimat tersebut dengan menjelaskan bentuk sari buahnya. Akibatnya diterjemahkan menjadi jus yang masih ada daging buahnya, atau dalam bahasa Inggris dengan jus yang masih mengandung daging buah di atasnya.

Kata sandal memiliki sedikit sinonim, sedangkan istilah mules memiliki arti tersebut. A mule adalah sandal wanita yang terbuka di sekitar tumit (A.S Hornby: 2000). Sehingga makna Mules diterjemahkan menjadi sandal tanpa hak atau sandal tanpa tumit.

Prase princess material terdiri dari dua kata yaitu putri dan materi. Namun jika kedua kata ini digabungkan, akan mempunyai arti yang berbeda. Princess material bisa diartikan sebagai hal-hal yang dibutuhkan untuk menjadi seorang putri. Untuk mendapatkan makna proporsional dalam bahasa target, strategi pharaprases using related word digunakan oleh penerjemah yang berarti sesuatu / 
seseorang cocok untuk menjadi seorang putri.

Tidak ada kata yang sepadan dalam bahasa target untuk menerjemahkan fixated. Dalam kamus Thesaurus, fixated memiliki kemiripan dengan terobsesi, diamati, terjebak, fanatik, asyik, sangat menyukai, dan paranoid. Dari kalimat yang diperoleh dari sumber bahasa memiliki makna bahwa "Mia selalu berkeinginan memasukkan sesuatu ke dalam mulutnya”, Namun, istilah tersebut diterjemahkan berbeda oleh Donna dengan memparafrasekan istilah tersebut menjadi "telat dalam fase perkembangan lisan atau terlambat dalam fase perkembangan lisan" yang menunjukkan alasan mengapa Mia menjadi suka melakukan hal tersebut. Iconoclastic berarti mengkritik akan kepercayaan, atau membangun sebuah adat dan paradigma baru. (Hornby: 2000). Namun, istilah tersebut tidak ditemui dalam bahasa target. Dengan demikian, strategi penerjemahan dengan parafrase digunakan menjadi gaya yang mendobrak kemapanan. Gaya merepresentasikan arti gaya dan mendobrak pertunjukan ktitik atau menerobos kemapanan, yang merupakan kondisi umum dari sesuatu yang mantap dan mapan.

Berdasarkan Oxford Advance Learner's Dictionary (2000: 75), prasa be off my back adalah istilah yang berarti berhenti mengganggu seseorang. Namun tidak ada istilah atau idiom khusus untuk mendeskripsikan istilah ini dalam bahasa target. Jadi penerjemah menerjemahkannya dengan istilah tersebut menjadi "tidak akan merepotkanku atau tidak akan mengganggu saya."

Sedangkan untuk istilah human $Q$-type dalam bahasa sasarannya adalah 'manusia yang mengenakan kapas untuk telinga/cotton'. Namun, hal tersebut tidak merepresentasikan makna akurat yang ingin disampaikan dalam bahasa sasaran. Konsekuensinya, Donna Widjajanto menggunakan strategi penerjemahan dengan parafrase menggunakan kata terkait. Dia menerjemahkan kalimat itu menjadi manusia yang benar-benar aneh, atau orang yang benar-benar asing. Dia terus menggunakan kata manusia, tapi dia memodifikasi istilah Q-tip "menjadi benar-benar aneh".

Kata republican dalam bahasa Indonesia secara leksikal berarti republik. Meski demikian, tidak ada istilah khusus yang memiliki arti yang sama. Dalam Oxford Advance Learner's Dictionary (2000: 12083) republican adalah orang yang mendukung suatu bentuk pemerintahan dengan presiden dan politisi yang dipilih oleh rakyat tanpa raja atau ratu atau pendukung Partai Republik. Rupanya makna kedua sesuai dengan pesan bahasa sumber yang ingin disampaikan oleh novelis, yang bermakna "Pendukung Partai Republik".

Tidak ada kata khusus untuk menerjemahkan "a big whiner" dalam bahasa target. Selain itu, diambil dari istilah whine yang artinya mengeluh dengan suara tangis yang mengganggu. Maka untuk menerjemahkannya Donna menggunakan istilah "senang sekali berkeluh kesah".

Strategi penerjemahan kata hyperventilating berdasarkan Oxford Advance Learner's Dictionary (2000: 639) artinya bernapas terlalu cepat, disebabkan oleh ketakutan atau kegembiraan. Dalam bahasa sasaran, istilah tersebut diartikan sebagai bisa bernafas kembali atau bisa mulai bernafas lagi. Terjemahan mengacu pada kondisi yang akan terjadi ketika Anda menghentikan hiperventilasi sehingga Anda dapat berventilasi lagi.

Istilah Disney Fication tidak memiliki istilah padanan dalam bahasa target. 
Istilah ini berasal dari kata Disney yang merupakan nama perusahaan entertainment besar, yang memproduksi kartun, buku, film, dll. Selanjutnya, beberapa morfem terikat, yaitu sufiks -ify (yang biasanya membentuk verba disnify) dan biasanya membentuk kata benda disneyfication) membangun makna baru. Untuk menemukan terjemahan yang proporsional dalam bahasa target, Donna menerjemahkan kata Disney Fication menjadi "diracuni oleh Disney atau keracunan Disney".

Class valedictorian adalah sebutan untuk siswa yang memiliki nilai tertinggi di kelas tertentu di suatu sekolah dan kepadanya akan diberikan kesempatan untuk berpidato untuk mengucapkan selamat tinggal pada suatu upacara kelulusan. Sayangnya kebiasaan ini tidak populer di budaya kita. Dengan demikian tidak ada istilah yang memiliki arti serupa dalam bahasa sasaran. Akibatnya, Donna menggunakan strategi yang diterjemahkan dengan parafrase menggunakan kata-kata yang tidak berhubungan. Makna item bahasa sumber dikeluarkan dan dimodifikasi dalam bahasa target menjadi murid terpandai yang akan membacakan pidato wisuda angkatannya. Meskipun istilah tersebut diterjemahkan secara berbeda, tetapi masih mewakili arti sampai batas tertentu.

Istilah literacy secara leksikal berarti melek huruf. Namun demikian, penerjemah menggunakan strategi lain untuk menerjemahkan istilah tersebut. Makna buta huruf memiliki frekuensi yang lebih tinggi untuk digunakan. Oleh karena itu, agar lebih natural dalam bahasa sasaran, Donna Widjajanto menerapkan strategi penerjemahan parafrase menggunakan kata-kata yang berhubungan. Karena istilah buta huruf lebih familiar dibandingkan dengan melek huruf, maka penerjemah memparafrasekan frasa tersebut menjadi kebalikannya yaitu buta huruf. Ia menjelaskan bahwa Islandia memiliki tingkat buta huruf terendah di dunia yang diterjemahkan ke dalam bahasa target menjadi tingkat buta huruf Eslandia paling rendah di dunia.

Istilah terakhir yang menggunakan strategi pharaprases adalah Mules. Karena dalam Bahasa Indonesia kurang memiliki istilah khusus untuk istilah sandal. Padahal, istilah bagal dalam bahasa target merupakan hiponim untuk itu. Bagal adalah sepatu wanita yang terbuka di sekitar tumit (A.S Hornby: 2000). Alhasil diterjemahkan dengan mendeskripsikan bentuknya menjadi sandal tanpa hak atau sandal tanpa tumit.

\section{3) Terjemahan menggunakan paraphrases using unrelated word}

Paraphrase using unrelated word didasarkan pada modifikasi super ordinat atau sekadar membongkar makna sumber bahasa, terutama jika pokok/kata/phrase tersebut secara makna semantik yang kompleks.

\section{Table 4.3 Strategy Paraphrase using} Unrelated Words

\begin{tabular}{|c|c|c|c|}
\hline \multirow{2}{*}{$\begin{array}{l}\mathrm{N} \\
\mathrm{O}\end{array}$} & Pag & \multirow{2}{*}{$\begin{array}{l}\text { Original } \\
\text { words/ } \\
\text { Phrases }\end{array}$} & \multirow[b]{2}{*}{ Translation } \\
\hline & $\begin{array}{l}\text { SL/ } \\
\text { TL }\end{array}$ & & \\
\hline 1 & $\begin{array}{l}3 / 1 \\
1\end{array}$ & Flunking & Nilai jelek \\
\hline 2 & $\begin{array}{l}12 / \\
21 \\
\end{array}$ & Unadulterated & $\begin{array}{l}\text { Keajaiban } \\
\text { berjalan }\end{array}$ \\
\hline 3 & $\begin{array}{l}21 / \\
31 \\
\end{array}$ & Principality & $\begin{array}{l}\text { Dipimpin } \\
\text { pangeran }\end{array}$ \\
\hline 4 & $\begin{array}{l}23 / \\
35\end{array}$ & $\begin{array}{l}\text { To go curl up } \\
\text { some place } \\
\text { and die }\end{array}$ & Terjun ke jurang \\
\hline 5 & $\begin{array}{l}62 / \\
76\end{array}$ & A wanker & Memang payah \\
\hline
\end{tabular}




\begin{tabular}{|c|c|c|c|}
\hline 6 & $\begin{array}{l}120 \\
/ 13 \\
9\end{array}$ & Sappy & $\begin{array}{l}\text { Cerita tentang } \\
\text { orang yang suka } \\
\text { bekerja } \\
\text { Keras }\end{array}$ \\
\hline 7 & $\begin{array}{l}123 \\
/ 14 \\
3\end{array}$ & $\begin{array}{l}\text { That's all I } \\
\text { need }\end{array}$ & $\begin{array}{l}\text { Sama sekali tidak } \\
\text { ingin }\end{array}$ \\
\hline 8 & $\begin{array}{l}29 / \\
42 \\
\end{array}$ & $\begin{array}{l}\text { A huge pain in } \\
\text { the ass }\end{array}$ & $\begin{array}{l}\text { Memang sangat } \\
\text { menyebalkan }\end{array}$ \\
\hline 9 & $\begin{array}{l}43 / \\
55\end{array}$ & Muses & $\begin{array}{l}\text { Sembilan dewi } \\
\text { yunani yang } \\
\text { member } \\
\text { inspirasi kepada } \\
\text { para seniman }\end{array}$ \\
\hline $\begin{array}{l}1 \\
0\end{array}$ & $\begin{array}{l}58 / \\
63\end{array}$ & Cracks up & Sangat jengkel \\
\hline $\begin{array}{l}1 \\
1\end{array}$ & $\begin{array}{l}51 / \\
64\end{array}$ & Big Time & $\begin{array}{l}\text { Dimarahi habis- } \\
\text { habisan }\end{array}$ \\
\hline $\begin{array}{l}1 \\
2 \\
\end{array}$ & $\begin{array}{l}52 / \\
66\end{array}$ & Ovo-lacto & $\begin{array}{l}\text { Aku mau makan } \\
\text { telur }\end{array}$ \\
\hline $\begin{array}{l}1 \\
3 \\
\end{array}$ & $\begin{array}{l}62 / \\
76 \\
\end{array}$ & Covered & $\begin{array}{l}\text { Tidak akan } \\
\text { membutuhkanny } \\
\text { a }\end{array}$ \\
\hline $\begin{array}{l}1 \\
4 \\
\end{array}$ & $\begin{array}{l}63 / \\
78\end{array}$ & A head case & $\begin{array}{l}\text { Aku punya } \\
\text { masalah besar }\end{array}$ \\
\hline $\begin{array}{l}1 \\
5 \\
\end{array}$ & $\begin{array}{l}72 / \\
88\end{array}$ & Put out & $\begin{array}{ll}\text { Yang } & \text { bisa } \\
\text { ditiduri } & \\
\end{array}$ \\
\hline $\begin{array}{l}1 \\
6\end{array}$ & $\begin{array}{l}80 / \\
97\end{array}$ & Coeducational & $\begin{array}{l}\text { Yang menerima } \\
\text { murid } \\
\text { perempuan }\end{array}$ \\
\hline $\begin{array}{l}1 \\
7\end{array}$ & $\begin{array}{l}96 / \\
115\end{array}$ & Got to give & $\begin{array}{l}\text { Pasti ada yang } \\
\text { salah }\end{array}$ \\
\hline $\begin{array}{l}1 \\
8\end{array}$ & $\begin{array}{l}114 \\
/ 13 \\
4\end{array}$ & Twink & Tidak istimewa \\
\hline $\begin{array}{l}1 \\
9 \\
\end{array}$ & $\begin{array}{l}120 \\
/ 13 \\
9\end{array}$ & There you go & $\begin{array}{l}\text { Jelaskan } \\
\text { perbedaannya }\end{array}$ \\
\hline $\begin{array}{l}2 \\
0\end{array}$ & $\begin{array}{l}126 \\
/ 14 \\
6\end{array}$ & Frumpy & $\begin{array}{l}\text { Orang-orang } \\
\text { yang tidak bisa } \\
\text { berdansa }\end{array}$ \\
\hline $\begin{array}{l}2 \\
1 \\
\end{array}$ & $\begin{array}{l}155 \\
/ 17 \\
7\end{array}$ & The jocks & Anak-anak gaul \\
\hline
\end{tabular}

\begin{tabular}{|c|c|c|c|}
\hline 2 & $\begin{array}{l}150 \\
/ 17 \\
1\end{array}$ & An embolism & $\begin{array}{l}\text { Penyumbatan } \\
\text { pembuluh darah }\end{array}$ \\
\hline $\begin{array}{l}2 \\
3\end{array}$ & $\begin{array}{l}176 \\
/ 19 \\
8\end{array}$ & $\begin{array}{lr}\text { No } & \text { cause } \\
\text { stands } & \text { a } \\
\text { chance } & \end{array}$ & \begin{tabular}{ll}
\multicolumn{2}{c}{ Tanpa dukungan } \\
selebriti tidak \\
akan \\
Berhasil
\end{tabular} \\
\hline $\begin{array}{l}2 \\
4\end{array}$ & $\begin{array}{l}220 \\
/ 24 \\
4\end{array}$ & $\begin{array}{l}\text { Hebbie- } \\
\text { jebbies }\end{array}$ & $\begin{array}{l}\text { Bulu kudukku } \\
\text { mulai merinding }\end{array}$ \\
\hline $\begin{array}{l}2 \\
5\end{array}$ & $\begin{array}{l}249 \\
/ 27 \\
6\end{array}$ & A frivolous & $\begin{array}{l}\text { Tidak } \\
\text { enteng }\end{array}$ \\
\hline
\end{tabular}

Dalam strategi paraphrase using unrelated word penerjemah menerapkan strategi penerjemahan dengan menggunakan parafrase dari kata-kata yang tidak berhubungan. Strategi tersebut dilakukan sebanyak 25 kali.

Flunking diambil dari kata sifat flunk yang artinya gagal dalam ujian dan penerjemah memilih kata nilai jelek untuk menggantikannya. Donna Widjajanto menerapkan strategi penerjemahan dengan parafrase menggunakan kata-kata yang tidak berhubungan. Meski mendapat nilai jelek tidak selalu berarti gagal, namun kedua ungkapan tersebut, gagal dan mendapatkan nilai jelek, memiliki kesamaan 'makna proporsional'. Memang masih ada hubungan sebab akibat yang berhubungan dengan arti kata-katanya.

Namun, seperti yang telah dikatakan sebelumnya dalam temuan strategi penerjemahan dengan kata yang lebih umum pada bahasan pertama, yang dimaksud dengan hot dalam konteks ini adalah baru, sudah ada, dan sangat populer. Pada istilah unadulterated artinya murni. Meskipun demikian, arti pasti yang ingin dicapai dalam bahasa target bukanlah kesegaran murni. Untuk mendapatkan makna proporsional yang ingin dicapai dari Bahasa sumber ke Bahasa target, penerjemah menggunakan strategi penerjemahan menggunakan kata 
yang tidak berhubungan. Frase unadulterated hotness diterjemahkan menjadi keajaiban berjalan. Panas diartikan sebagai sesuatu yang tidak bisa dipercaya yang bisa terjadi atau dengan kata lain mukjizat. Penerjemah mengartikannya sebagai sesuatu yang mengharukan. Hal ini bertujuan untuk menjelaskan informasi selanjutnya yang ingin diberikan, bahwa seseorang yang dianggap mukjizat masih hidup dan memiliki tinggi setinggi enam kaki. Belum lagi, karena di Indonesia pengukuran kaki masih asing, maka penerjemah menyusun ulang dalam ukuran meteran.

Sebenarnya principality memiliki persamaan yang hampir sama di Indonesia yaitu kerajaan. Namun istilah ini berbeda bentuknya. Kerajaan jauh lebih mirip dengan monarki. Jadi, penerjemah menggunakan strategi penerjemahan dengan parafrase menggunakan kata-kata yang tidak berhubungan. Kerajaan diartikan sebagai bangsa yang diperintah oleh seorang pangeran (A.S Hornby: 2000). Apalagi disebutkan bahwa satusatunya yang lain adalah Monaco (hlm. 21). Akibatnya, istilah tersebut diparafrasekan menjadi Genovia dipimpin oleh seorang pangeran, atau dalam bahasa Indonesia Genovia dipimpin oleh pangeran.

To go curl up some place and die adalah sebuah phrase yang berarti "meringkuk di suatu tempat dan mati" yang digunakan untuk mengekspresikan ketidaksukaan ekstrim seseorang terhadap seseorang. Jika diterjemahkan kata demi kata maka akan dilakukan pergi melakukan hal yang memalukan di suatu tempat dan mati. Namun kalimat ini masih asing di telinga. Apalagi pesan yang ingin disampaikan penulis dalam bahasa sumber tidak proporsional dengan bahasa sasaran. Maka, Donna Widjajanto menerjemahkan kalimat tersebut menggunakan strategi dengan parafrase menggunakan kata-kata yang tidak berhubungan. Dia memparafrasekan kalimat menjadi terjun ke jurang atau melompat ke jurang. Terjun ke jurang dan melakukan hal yang memalukan di suatu tempat memiliki makna yang sama, yaitu melakukan sesuatu yang bodoh dan sia-sia. Frasa tersebut dapat menyampaikan apa yang dimaksud dengan frasa dari bahasa sumber ke bahasa sasaran.

A huge pain in the ass (rasa sakit yang sangat di bagian paha atas) adalah ungkapan yang diucapkan oleh Mia untuk mengungkapkan betapa dia kesal dengan sikap neneknya, yang selalu mengatakan kepadanya apa yang harus dilakukan untuk hal-hal yang bernilai. Namun, alihalih menerjemahkan frasa menjadi sakit yang amat sangat di bagian paha atas/pantat, Donna Widjajanto menggunakan strategi terjemahan dengan parafrase using unrelated word. Ia membongkar makna frasa yang memang sangat disebalkan menjadi memang sangat menyebalkan untuk mencari makna proporsional dari frasa yang merepresentasikan perasaan yang dirasakan Mia.

Strategi penerjemahan parafrase menggunakan kata-kata yang tidak berhubungan digunakan pada kalimat berikutnya Muses karena tidak ada dalam budaya dan bahasa target Indonesia. Ini adalah semangat yang memberi ide dan keinginan seniman untuk menciptakan sesuatu. Selain itu, dalam cerita Yunani dan Romawi kuno, muse adalah salah satu dari sembilan dewi yang mendorong puisi, musik, dan cabang seni dan sastra lainnya. Maka, penerjemah mengatasi masalah tersebut dengan memparafrasekan istilah renungan sembilan dewi Yunani, yang memberikan inspirasi kepada seniman 
atau Sembilan dewi yunani yang memberi inspirasi bagi seniman.

Menurut A.S. Hornby (2000: 291) crack somebody up membuat seseorang tertawa berarti membuat seseorang tertawa. Namun kata-kata tersebut berbeda dalam arti ekspresif yang dimaksudkan. Istilah crack me up dalam kalimat digunakan untuk menunjukkan perasaan Mia, yang begitu buruk tentang situasinya, bukan tentang hiburan yang bisa membuatnya tertawa. Dengan demikian strategi penerjemahan dengan parafrase menggunakan kata-kata yang tidak berhubungan digunakan. Alih-alih menerjemahkannya menjadi sesuatu yang membuat Mia senang, Donna menerjemahkan istilah tersebut dengan menggambarkan perasaan Mia yang sangat marah, atau dalam bahasa Indonesia sangat jengkel.

Covered diambil dari kata cover yang dalam bahasa Indonesia berarti tutup, kain penutup, sampul, perlindungan, (Gema dan Shadily: 1996). Namun makna tersebut belum mampu merepresentasikan informasi dari bahasa sumber secara proporsional. Oleh karena itu, diterapkan strategi penerjemahan dengan parafrase menggunakan kata-kata yang tidak berhubungan. Istilah yang tercakup dalam kalimat tersebut dimaksudkan untuk menjelaskan kondisi selanjutnya yang diceritakan dari kalimat sebelumnya, "Ngomong-ngomong, untuk apa saya perlu mengetahui aljabar? Mereka tidak menggunakan Aljabar di Greenpeace. Dan Anda yakin Anda tidak membutuhkannya jika Anda seorang putri. Jadi bagaimanapun hasilnya, saya tertutup "(hlm. 62). Oleh karena itu penerjemah menafsirkan istilah yang tercakup dalam bahasa sasaran menjadi tidak akan membutuhkannya lagi, atau tidak akan membutuhkannya (Aljabar) lagi sebagai fakta dalam cerita.

Ovo-lacto adalah istilah khusus di bidang medis. Namun, bahasa target tidak memiliki hiponim yang dapat menafsirkan istilah tersebut dengan baik. Jadi, penerjemah menggunakan terjemahan dengan parafrase menggunakan kata-kata yang tidak berhubungan. Katanya saya bukan lagi ovo-lacto, dan diterjemahkan ke dalam bahasa saya mau makan telur, yang jelas ada ungkapan "saya sudah tidak ada lagi". Dengan demikian, penulis menemukan bahwa ovo-lacto dapat diartikan sebagai orang yang takut atau tidak pernah makan telur. Selain itu, penerjemah memparafrasekan makna tersebut menjadi kebalikannya bahwa saya (Mia) ingin makan telur.

Wanker (BrE, tabu, gaul) adalah kata yang tidak sopan untuk digunakan dalam menghina seseorang, terutama pria, dan untuk menunjukkan kemarahan atau ketidaksukaan (A.S. Hornby: 2000). Karenanya, bahasa target tidak memiliki kata khusus untuk menggantikan wanker. Oleh karena itu penerjemah menggunakan strategi terjemahan dengan parafrase menggunakan kata yang tidak berhubungan untuk ditangani. Diterjemahkan menjadi memang payah pasti menunjukkan ketidaksukaan dan kemarahan.

Dalam bahasa sumber, istilah head case ada untuk mewakili seseorang yang tampaknya sakit jiwa dan berperilaku aneh. Namun tidak ada istilah khusus dalam bahasa target untuk mewakili orang seperti itu. Selain itu istilah tersebut tidak dileksikalisasi dalam bahasa Indonesia. Hasilnya, diterapkan strategi penerjemahan dengan parafrase menggunakan kata yang tidak berhubungan. Arti yang diterjemahkan menjadi aku punya masalah besar. 
Terjemahan ini berkaitan dengan sikap yang biasanya dibuat oleh seseorang yang memiliki masalah besar yang terkadang menjadi aneh dan ganjil.

Istilah put out dalam bahasa sumber adalah kata gaul yang artinya setuju untuk berhubungan seks dengan seseorang (A.S. Hornby: 2000). Istilah ini tidak dileksikalisasi di Indonesia. Dengan demikian strategi penerjemahan menggunakan kata-kata yang tidak berhubungan diterapkan. Karena di Indonesia berbicara tentang seks dianggap sebagai hal yang tabu, maka istilah yang bisa ditiduri diterjemahkan secara sopan dan tersirat menunjukkan suatu aktivitas seks, tanpa mengungkapkannya secara pas-pasan dengan istilah tertentu.

Coeducational adalah istilah yang berkaitan dengan sistem pendidikan dimana anak laki-laki dan perempuan diajar bersama. Karena istilah tersebut tidak memiliki istilah khusus dalam bahasa target, maka strategi penerjemahan menggunakan kata-kata yang tidak berhubungan diterapkan. Penerjemah membongkar item bahasa sumber dalam bahasa target untuk menerima murid perempuan yang memiliki arti yang sama dengan anak laki-laki dan perempuan belajar bersama di satu sekolah.

Go to give adalah istilah kiasan yang tidak ada dalam bahasa target. Harus memberikan pertunjukan yang tidak masuk akal tentang berkorban jika kita ingin sesuatu berjalan lancar. Selain itu, tidak akan ada yang salah jika kita ingin berkorban untuk mencapai tujuan. Dengan demikian strategi penerjemahan menggunakan kata-kata yang tidak berhubungan diterapkan untuk mencapai makna yang proporsional dalam bahasa sasaran. Got to give diartikan bahwa ada yang salah, atau dalam bahasa target pasti ada yang salah.
Istilah twink tidak terdapat dalam bahasa kamus bahasa Indonesia. Bahkan dalam bahasa sumbernya sendiri istilah tersebut ditulis dengan koma terbalik. Untuk mengatasi hal tersebut, penerjemah menggunakan strategi penerjemahan dengan parafrase menggunakan kata-kata yang tidak berhubungan. Jadi diterjemahkan menjadi tidak istimewa. Sebutan tidak istimewa artinya tidak istimewa atau polos yang secara tersirat dalam cerita Nenek Mia tidak menganggap Putri Diana adalah orang yang luar biasa sehingga ia membandingkannya dengan yang lain dan menganggap bahwa urutannya lebih baik. "Tapi Grandmere berkata bahwa wanita sejati adalah Putri Grace dan Coco Chanel (p. 144)".

Ungkapan dalam keberadaan digunakan untuk berbicara tentang sesuatu yang terjadi dengan cara yang khas atau tentang situasi yang tidak dapat diubah. Mia memang bercerita tentang Joan dan membandingkannya dengan situasi yang terjadi dengan teman-temannya yang khas. "Saya tidak percaya bahwa Joan menderita skizofrenia onset remaja. Saya pikir malaikat benar-benar berbicara dengannya. Tak satu pun penderita skizofrenia di sekolah kami yang suaranya menyuruh mereka melakukan sesuatu yang keren seperti memimpin negara mereka ke medan perang. Semua suara Brandon Hertzenbaum menyuruhnya pergi ke kamar anak laki-laki dan mengukir "Setan" di pintu ke kamar mandi dengan busur derajat. There you go '(hlm. 120). Dengan demikian, strategi penerjemahan yang dipilih oleh Donna untuk menerjemahkan frasa tersebut adalah dengan memparafrasekannya menggunakan kata-kata yang tidak berhubungan. Diterjemahkan untuk menjadi perbedaannya. Terjemahan 
menunjukkan perbedaan yang ditunjukkan oleh perbandingan.

Istilah sappy memiliki kemiripan dengan konyol dan sentimental. Selain itu, Hasan Shadily dan John M. Echols (1996) menerjemahkan istilah tersebut menjadi gila-gilaan dan stupid. Tentunya istilah dalam bahasa sasaran tidak mewakili makna yang ingin disampaikan dalam bahasa sasaran tersebut. Kalimat sebelumnya menceritakan tentang kisah buku favorit Mia. Memang, itu tidak menunjukkan sesuatu yang gila atau konyol. Di sisi lain memang sedikit sentimental, tapi ada yang lebih dari itu, menceritakan tentang upaya heroin dalam menghadapi hidupnya. "Christy (pahlawan wanita) adalah seorang gadis muda yang pergi ke sekolah untuk mengajar di Smoky Mountain pada pergantian abad karena dia percaya dia bisa membuat perbedaan, dan semua pria seksi ini jatuh cinta padanya dan dia belajar tentang tuhan dan tifus dan sejenisnya "(hlm. 120). Akibatnya, strategi penerjemahan dengan parafrase menggunakan kata-kata yang tidak berhubungan diterapkan. Berdasarkan uraian cerita buku favorit Mia diterjemahkan menjadi ceritanya tentang orang yang suka bekerja keras.

Frasa yang saya butuhkan diterjemahkan dengan strategi parafrase menggunakan kata-kata yang tidak berhubungan. Namun, terjemahan diubah menjadi kebalikannya dalam bahasa target untuk menyampaikan makna yang tepat yang ingin disampaikan oleh novelis. Demikian kalimat tersebut diterjemahkan menjadi I really do want atau aku sama sekali tidak ingin. Itu yang saya butuhkan dalam bahasa sumber adalah semacam sindiran tentang apa yang terjadi. Itu bisa dilihat dari kalimat-kalimat sebelumnya. "Dan aku tidak bisa memperkenalkannya sekarang karena nanti Lily akan mengetahui bahwa aku adalah putri Genovia, dan kamu bisa bertaruh aku tidak akan pernah memanaskannya. Dia mungkin ingin mewawancarai saya atau sesuatu untuk acara TV-nya (p. 123)"

Frumpy merupakan kata sifat dari istilah frump yang artinya adalah wanita yang memakai pakaian yang tidak modis (A.S. Hornby: 2000). Karena bahasa target tidak memiliki istilah khusus untuk menggantikan istilah tersebut, strategi terjemahan dengan parafrase menggunakan kata-kata yang tidak berhubungan digunakan. Penerjemah menjelaskan artinya dalam bahasa target dengan beberapa penyesuaian yang dapat diterima. Akibatnya diterjemahkan menjadi orang-orang yang tidak bisa berdandan atau dalam bahasa target orangorang yang tidak bisa berdandan.

Berdasarkan Kamus Inggris-Indonesia yang ditulis oleh John Echols dan Hasan Shadily, istilah emboli diterjemahkan menjadi emboli. Namun, tidak setiap orang dapat memahami apa itu emboli, karena itu adalah istilah khusus di bidang medis. Maka untuk memperjelas bahasa sasaran, penerjemah menggunakan strategi penerjemahan dengan menggunakan kata-kata yang tidak berhubungan. Akibatnya Donna memparafrasekan istilah bahasa sumber untuk menjelaskan artinya menjadi penyumbatan pembuluh darah atau penyumbatan pembuluh darah.

Istilah atlet tidak dileksikalisasi dalam bahasa target. Selain itu, dalam Oxford Advance Learner's Dictionary (2000: 697) ini adalah cara untuk mendeskripsikan seseorang dari Skotlandia yang dapat menyinggung. Namun makna ini jelas terlihat aneh sebagai interpretasi istilah dalam kalimat. Dengan demikian, strategi penerjemahan dengan parafrase 
menggunakan kata-kata yang tidak berhubungan diterapkan. Para atlet diartikan sebagai anak-anak gaul. Selain itu, istilah gaul sendiri secara implisit menunjukkan adanya tindakan ofensif di masyarakat.

Berdiri perubahan adalah ungkapan berarti memiliki kemungkinan (Dixson: 1971), sedangkan, tidak ada sebab yang memiliki kesamaan tanpa alasan. Istilah tersebut dapat diartikan tidak ada alasan untuk memiliki kemungkinan, atau dalam bahasa target tidak ada alasan untuk mendapatkan kesempatan. Namun, penerjemah menggunakan strategi terjemahan lain untuk mendapatkan interpretasi yang akurat dalam bahasa target. Dia menerapkan strategi terjemahan dengan parafrase menggunakan kata-kata yang tidak berhubungan. Istilah tersebut diterjemahkan

menjadi tidak aka nada yang berhasil atau dalam bahasa sumber tidak ada yang akan berhasil. Padahal frase tidak aka ada yang berhasil merupakan suatu kondisi yang tercipta bila tidak ada alasan untuk melakukan perubahan dalam melakukan sesuatu.

Istilah heebie-jebies tidak dileksikalisasikan dalam bahasa target. Dengan demikian, strategi penerjemahan dengan parafrase menggunakan kata-kata yang tidak berhubungan digunakan. Strategi penerjemahan ini digunakan untuk mendapatkan tingkat makna proporsional tertinggi dalam bahasa target. Dengan demikian, penerjemah dapat dengan leluasa menafsirkan maknanya. Alhasil, frasa tersebut diterjemahkan menjadi bulu kudukku mulai merinding. Namun, bahasa target entah bagaimana mampu menafsirkan item bahasa sumber.

Dalam Oxford Advance Learner's Dictionary (2000: 517), sembrono berarti konyol atau lucu, terutama bila perilaku seperti itu tidak cocok: tidak memiliki tujuan yang berguna atau serius. Ternyata John Echols dan Hasan Shadily sudah menemukan terjemahannya dalam Kamus Inggris Indonesia (1996: 258) yaitu sembrono, tidak karuan. Namun, terjemahan bahasa target tidak dapat mencapai makna yang sesuai untuk pembaca bahasa target. Akibatnya Donna Widjajanto menggunakan strategi penerjemahan dengan parafrase menggunakan kata yang tidak berhubungan menjadi tidak akan enteng. Selain itu, perhatikan bahwa istilah tidak dicetak miring. Artinya, Donna menekankan kata itu. Menerjemahkan tem tersebut ke dalam bentuk negatif yang memiliki maksud yang sama dengan frasa bahasa sumber tidak akan mudah.

\section{4) Terjemahan menggunakan \\ Omission}

Jika makna yang disampaikan oleh item atau ungkapan tertentu tidak cukup penting bagi perkembangan teks untuk membenarkan pengalihan perhatian pembaca dengan penjelasan yang panjang, penerjemah dapat dan sering kali tidak begitu saja menerjemahkan kata atau ungkapan yang dimaksud.

\section{Table.4.4 Strategies by using Omission}

\begin{tabular}{|c|c|c|c|}
\hline & & & \\
\hline $\mathrm{N}$ & Pages & & \\
\hline 0 & $\begin{array}{l}\mathrm{SL} / \mathrm{T} \\
\mathrm{L}\end{array}$ & Phrases & on \\
\hline 1 & $3 / 11$ & Every single solitary & Setiap \\
\hline 2 & $\begin{array}{l}46 / 5 \\
9\end{array}$ & $\begin{array}{ll}\text { The } & \text { snobby } \\
\text { doorman } & \end{array}$ & $\begin{array}{l}\text { Penjaga } \\
\text { pintu }\end{array}$ \\
\hline 3 & $\begin{array}{l}53 / 4 \\
7 \\
\end{array}$ & But whatever & $\begin{array}{l}\text { Untransl } \\
\text { ated }\end{array}$ \\
\hline 4 & $\begin{array}{l}99 / 1 \\
18 \\
\end{array}$ & The parquet & $\begin{array}{l}\text { Untransl } \\
\text { ated }\end{array}$ \\
\hline 5 & $\begin{array}{l}116 / \\
136\end{array}$ & $\begin{array}{l}\text { Groundbreaking } \\
\text { investigation }\end{array}$ & $\begin{array}{l}\text { Investiga } \\
\text { si }\end{array}$ \\
\hline 6 & $\begin{array}{l}157 / \\
180\end{array}$ & Jet line & $\begin{array}{l}\text { Untransl } \\
\text { ated }\end{array}$ \\
\hline
\end{tabular}




\begin{tabular}{|l|l|l|l|}
7 & $\begin{array}{l}217 / \\
241\end{array}$ & $\begin{array}{l}\text { A freak, a dork a } \\
\text { greatnerd }\end{array}$ & $\begin{array}{l}\text { Untransl } \\
\text { ated }\end{array}$ \\
\hline
\end{tabular}

Penerjemah menggunakan kelalaian dalam menangani kata-kata setiap soliter. Dia hanya menerjemahkan kata itu ke setiap. Makna yang disampaikan oleh kata tunggal dan soliter tidaklah cukup penting dan hanya dapat direpresentasikan oleh setiap. Dengan demikian, tidak terlalu berdampak besar untuk menghilangkan kata-kata tersebut. Kata-kata selanjutnya tetapi apapun yang tidak diterjemahkan ke dalam bahasa sasaran, karena tidak memberikan pengaruh yang besar terhadap keseluruhan makna kalimat. Apalagi informasi dari bahasa sumber telah disampaikan dalam bahasa sasaran.

Karena istilah sombong tidak penting dan tidak berpengaruh besar dalam penerjemahan bahasa sasaran, maka penerjemah menghilangkan istilah tersebut dan langsung menerjemahkan kata sombong ke penjaga pintu.

Parket adalah sejenis penutup lantai yang terbuat dari potongan kayu datar yang disatukan dalam pola. (A.S. Hornby: 2000). Sayangnya, tidak ada istilah khusus dalam bahasa target yang bisa menggantikannya. Namun karena makna kalimat tersebut tidak memberikan pengaruh yang besar terhadap keseluruhan makna kalimat tersebut, maka penerjemah menghilangkannya dalam bahasa sasaran. Sekali lagi strategi terjemahan dengan kelalaian diterapkan. Istilah ground breaking yang artinya menggunakan metode baru (A.S. Hornby: 2000) tidak diterjemahkan. Penerjemah langsung menerjemahkan kata-kata berikutnya karena istilah tersebut tidak terlalu esensial yang dapat memberikan pengaruh yang besar pada bahasa sasaran.

Karena istilah jet line dalam kalimat tidak berdampak besar dalam bahasa target, penerjemah menggunakan strategi kelalaian untuk mengatasinya. Selain itu, istilah tersebut belum dileksikalisasi dalam bahasa target. Jadi, menghilangkan istilah dalam bahasa target tidak akan mengubah arti teks bahasa sumber secara besar-besaran.

Istilah dork, great, nerd hampir mirip dengan freak yang dalam bahasa target berarti orang aneh. Jadi, meskipun bahasa target tidak memiliki istilah khusus untuk menggantikan istilah bahasa sumber a dork, a great, dan nerd, itu tidak membuat dampak yang sangat besar dalam teks. Alhasil, Donna Widjajanto memilih menggunakan strategi penerjemahan dengan menghilangkan istilah-istilah tersebut. Karena maknanya secara umum sama dengan istilah freak yang sudah diterjemahkan ke dalam bahasa target sebelumnya.

5) Terjemahan Menggunakan Substitusi Budaya Penerjemahan dengan substitusi budaya melibatkan penggantian item atau ekspresi budaya tertentu dengan item bahasa target, yang tidak memiliki makna proposisional yang sama tetapi kemungkinan memiliki dampak serupa pada pembaca target. Keuntungannya adalah pembaca dapat mengidentifikasi konsep yang familiar bagi pembacanya.

\section{Table.4.5. Translation by using Cultural Substitution}

\begin{tabular}{|c|c|c|c|}
\hline $\mathrm{N}$ & $\begin{array}{l}\text { Page } \\
s\end{array}$ & \multirow{2}{*}{$\begin{array}{c}\text { Original words/ } \\
\text { Phrases }\end{array}$} & \multirow{2}{*}{ Translation } \\
\hline 0 & $\begin{array}{l}\mathrm{SL} / \mathrm{T} \\
\mathrm{L}\end{array}$ & & \\
\hline 1 & $1 / 9$ & It is really neat & Itu asyik \\
\hline 2 & $3 / 11$ & He is cool & Keren \\
\hline 3 & $4 / 16$ & Anyway & Yah \\
\hline
\end{tabular}




\begin{tabular}{|c|c|c|c|}
\hline 4 & $\begin{array}{l}7 \\
/ 21\end{array}$ & Hottest guys & $\begin{array}{l}\text { Cowok } \\
\text { palong } \\
\text { keren }\end{array}$ \\
\hline 5 & $\begin{array}{l}20 / 3 \\
0\end{array}$ & Literacy rate & Buta huruf \\
\hline 6 & $\begin{array}{l}21 / 3 \\
1\end{array}$ & Principality & $\begin{array}{l}\text { Dipimpin } \\
\text { pangeran }\end{array}$ \\
\hline 7 & $\begin{array}{l}30 / 6 \\
6\end{array}$ & Cooing & $\begin{array}{l}\text { Berdekut- } \\
\text { dekut }\end{array}$ \\
\hline 8 & $\begin{array}{l}55 / 1 \\
05\end{array}$ & Such a jerk & Brengsek \\
\hline 9 & $\begin{array}{l}79 / 1 \\
46\end{array}$ & Unfashionable & $\begin{array}{l}\text { Tidak bisa } \\
\text { dandan }\end{array}$ \\
\hline $\begin{array}{l}1 \\
0\end{array}$ & $\begin{array}{l}79 / 1 \\
46\end{array}$ & Stylist & Tampil gya \\
\hline $\begin{array}{l}1 \\
1\end{array}$ & $\begin{array}{l}137 / \\
311 \\
\end{array}$ & Shots; Score & Asyik,asyik \\
\hline $\begin{array}{l}1 \\
2\end{array}$ & $\begin{array}{l}156 / \\
174\end{array}$ & $\begin{array}{l}\text { Fight longest } \\
\text { "holding a grudge" }\end{array}$ & $\begin{array}{l}\text { Tahan } \\
\text { harga }\end{array}$ \\
\hline $\begin{array}{l}1 \\
3\end{array}$ & $\begin{array}{l}10 / 2 \\
8\end{array}$ & Vain & Sok cakep \\
\hline
\end{tabular}

Dari novel kedua versi tersebut hanya ada 13 masalah yang ditangani dengan strategi Pergantian Budaya. Donna Widjajanto tampaknya memilih strategi tersebut sebagai pilihan terakhirnya untuk mengatasi masalah tersebut.

Ini mentransfer kata-kata budaya dan mempertahankan derajat 'kelainan' gramatikal dan leksikal (penyimpangan dari norma SL) dalam terjemahan. Ini mencoba untuk sepenuhnya setia pada niat dan realisasi teks dari penulis SL. " Faktanya, dia menggunakan sejumlah strategi yang berhubungan dengan nonekivalen pada tingkat kata. Dengan demikian pembaca bahasa sasaran dapat memiliki makna yang sesuai yang ingin disampaikan oleh novelis tersebut. Misalnya kalimat "Dia tidak terlalu keren jika gagal Aljabar, seperti saya (p.3)" diterjemahkan menjadi "Dia tidak terlalu keren kalau nilai aljabarmu jelek, seperti aku (p.11). juga kalimat "Dia mengambil orang-orang yang tidak modis, lusuh seperti saya, dan dia membuat mereka bergaya (p.126)" diterjemahkan menjadi "dia membuat orang-orang yang tidak bisa berdandan dan tidak mengikuti mode seperti aku menjadi tampil gaya (hal. 146). " Ditambah kalimat "Islandia memiliki angka melek huruf tertinggi di dunia" (hlm. 20) diterjemahkan menjadi Tingkat Buta huruf Eslandia paling rendah di dunia (hlm. 30) dan masih banyak lagi.

Tampak jelas bahwa Donna berusaha menyampaikan apa maksud sebenarnya dari novelis tersebut. Juga penerjemah dengan setia mentransfer substansi teks dengan mempertahankan esensi dari bahasa sumber (Bsu) ke bahasa target (Bsa). Seperti dalam kalimat "Inilah yang disebut azas (hlm. 21) diterjemahkan menjadi Genovia dipimpin pangeran (hlm. 31)". Terlepas dari modifikasi mode penerjemah menuju bentuk gramatikal dan leksikal, yang disebut kelainan tata bahasa dan leksikal oleh Newmark, Donna mempersembahkan terjemahan yang bagus untuk pembaca bahasa target dari novel yang dia berikan inti yang sama dari versi aslinya.

Meski ngomong-ngomong, tidak ada yang bisa dibandingkan, namun omong-omong bisa menyuarakannya dengan baik.

Seolah-olah di ekspresikan dengan cara menyarankan sesuatu. Dalam cerita Mia bercerita tentang komentarnya tentang Leonardo Dicaprio dalam film Titanic (hlm. 12). Menurutnya hal itu berkaitan dengan tahun 1998 yang artinya old fashion dan sama sekali tidak keren. Secara tersirat dia ingin menyarankan pria lain untuk masuk dalam daftar pria terpanas Lili. Untuk menemukan persamaan yang lebih dekat dari frasa tersebut, penerjemah menggunakan strategi terjemahan menggunakan substitusi budaya. Ada banyak ungkapan 
yang secara implisit mengisyaratkan Lily memilih pria lain.

Yang dimaksud dengan sia-sia dalam konteks berdasarkan cerita, adalah kondisi terlalu sombong atau sombong terhadap apa yang telah diraih, penampilan atau kemampuan. Untuk mencapai istilah terbaik yang dapat mengekspresikan situasi yang sama, strategi penerjemahan dengan substitusi budaya diterapkan sejak novel diproyeksikan untuk remaja, sehingga istilah tersebut disesuaikan dengan ekspresi remaja. Ungkapan sok cakep mampu merepresentasikan situasi dan kondisi seseorang yang merasa angkuh dan bangga dengan penampilan dan kemampuannya.

Dari kamus program Thesaurus peneliti mengetahui bahwa kata passe memiliki kemiripan dengan out-of-date atau outmoded. Selain itu, A.S Hornby (2000: 925) mengartikan bahwa ketinggalan zaman sebagai tidak lagi modis. Karena pembaca dalam bahasa sasaran adalah remaja, maka penerjemah menggunakan strategi penerjemahan dengan substitusi budaya yang dapat menyampaikan makna dari kata yang lewat. Basi banget secara proporsional mewakili kadaluwarsa, ketinggalan zaman, dan kuno. Selain itu sesuai dengan kebiasaan remaja dalam bahasa target.

Menyimpan dendam berarti menyimpan perasaan marah atau tidak suka terhadap seseorang karena sesuatu yang buruk yang telah mereka lakukan kepada Anda di masa lalu. Selain itu, dalam situasi di cerita ini, diceritakan bahwa Mia bertengkar dengan sahabatnya, Lily. Dan Lily tidak ingin berjalan atau bermain dengannya lagi sejak pertengkaran mereka. Namun, penerjemah menggunakan strategi terjemahan substitusi budaya untuk menafsirkan frasa dalam bahasa target yang tahan harga.
Selain itu, tahan harga adalah mengungkapkan perasaan seseorang terhadap seseorang untuk mempertahankan harga dirinya, biasanya setelah bertengkar atau sesuatu yang buruk di masa lalu.

Frase yang Dia bidik; dia mencetak gol! Ungkapkan kebahagiaan yang dirasakan Mia. Jadi, untuk menerjemahkan frasa, penerjemah menggunakan strategi penerjemahan dengan substitusi budaya. Donna menerjemahkan kata itu menjadi Asyik, asyik. Ungkapan ini tidak asing untuk diucapkan ketika seseorang mendapatkan hal yang hebat dan baik. Meskipun arti literal dari kedua frasa dalam setiap bahasa berbeda, tetapi item tersebut digunakan terutama untuk nilai ekspresifnya.

Berdasarkan tabel di atas dapat dilihat persentase strategi penerjemahan dari analisis data yaitu 128 kasus yang memuat 5 strategi penerjemahan. Terdapat 61 kasus kata pinjaman / kata pinjaman ditambah penjelasan atau 47, 66\%, 22 kasus parafrase kata terkait atau $17,19 \%$, 25 kasus kata tidak berhubungan dengan parafrase atau 19,53\%, 7 kasus penghilangan atau 5,47\%, dan 13 kasus terakhir pergantian budaya atau $10,15 \%$. Dari penjelasan tersebut dapat disimpulkan bahwa jenis strategi penerjemahan yang paling dominan adalah loan word atau loan words ditambah penjelasan dengan 61 kasus atau $47,66 \%$ kejadian.

\section{KESIMPULAN}

Terdapat 5 (lima) strategi penerjemahan untuk mengatasi permasalahan tingkat kata yang tidak setara dalam menerjemahkan novel "The Princess Diaries" yang ditulis oleh Meg Cabot yang diambil dari teori Mona Baker (1992); a. strategi menggunakan kata pinjaman atau kata pinjaman ditambah penjelasan 
terdapat (61 data), b. strategi menggunakan parafrase menggunakan kata terkait (22 data), c. strategi menggunakan parafrase kata yang tidak berhubungan (25 data), d. strategi menggunakan omission (7 data), dan e. strategi menggunakan substitusi budaya (13 data).

Jenis strategi penerjemahan yang dominan digunakan dalam penelitian ini adalah loan word atau loan words plus explanation. Terdapat (61 data) atau 47,66\% yang diperoleh dalam penelitian ini.

\section{DAFTAR PUSTAKA}

Albakry, M. (2004). Linguistic and cultural issues in literary translation. retrieved November 17 , 2006 from accurapid.com/journal/29lit er.htm

Arikunto, S. (1996). Prosedur Penelitian: Suatu pendekatan praktek. Jakarta: Rineka Cipta

Baker, M. 1992. In other Words a Course Book on Translation. London:Routledge.

Bassnet, Susan. (1996). Translation Studies: Revised Edition. England Routledge

Bell, Roger T. 1991. Translation and Translating: Theory and Practice. New York:Longman.

Bell, R. T. (1998). Psychological/cognitive approaches. In M. Baker (Ed), Routledge encyclopedia of translation studies. London \& New York: Routledge.

Catford, J.C. 1965. A Linguistic Theory of Translation: an Essay in AppliedLinguistics. London: Oxford University Press.

Culler,J.(1976). Structuralist poetics: structuralism, linguistics, and the study of literature. Cornell: Cornell University Press.

Dixson J.Robert.(1971). Essential idiom in English: Revised edition. United States of America Regents Publishing Compan

Djojosuroto,KandSumaryati,M.L.A.(200 4).Prinsip-prinsip dasar Penelitian Bahasa dan Sastra. Bandung: Nuansa

Echols, John $\mathrm{M}$ and Shadily, Hasan. (1992). Kamus Indonesia Inggris. Jakarta : PT. gramedia

Echols, John $\mathrm{M}$ and Shadily, Hasan (1996). An EnglishIndonesianDictionary.Jak arta:PT.Gramedia

Eppert, Franz, ed. 1982. Transfer and Translation in Language Learning and Teaching. Singapore University Press.

Fraenkel, jack R and Wallen, Norman E. (1993). How to design and evaluate research in Education. New York: mc Graw - Hill Inc.

Fromkin and Rodman. (1993). An Introduction to Language. United States of America:Harcourt Brace Collage Publisher

Gay,L.R.(1987).EducationalResearch:C ompetencie for Analysis and Application. Ohio: Merril Publishing Company

Hartono, Rudi. 2009. Teori Penerjemahan (A Handbook for Translator). Semarang: Cipta Prima Nusantara.

Hornby, A.S (2000). Oxford Advanced Learner's Dictionary. China: Oxford University Press

Jaaskelainen, R., (1999). Tapping the process: an explorative study of cognitive and effective factors involved in translating. Joensuu: University of Joensuu 
Jaaskelainen, R., (2005).Translation studies: what arethey?RetrievedNovember 11,2 006from www.hum.expertise.wo rkshop.

Karimi, Lotfollah.2007.Equivalence in Translation. Online

Khan, Mond. Syarif. (1990). Educational Research New Delhi: Ashih Publishing House journal/35equiv.htm [accessed $1 / 5 / 10]$

Krings, H.P. (1986). Translation problems and translation strategies of advanced

German learners of French. In J. House, \& S. BlumKulka(Eds.), Interlingualandinter cultural communication (pp. 26375). Tubingen

Kustanti, Havid. 2006. Equivalence at Word Level in the J.K Rowling's Novel Entitled"Harry Potter and the Chamber of Secrets". UNNES: unpublished.

Lance, Hewson. 1991. Redefining Translation, the Variational Approach. London:Routledge.

Larson, Mildred L. 1984. Meaning Based Translation:AGuidetoCrossLang uage Equivalence. Lanham: University Press of America

Leonardi,Vanessa.2000.Equivalencein Translation: Between Myth and Reality.

Loescher, W. (1991). Translation performance, translationprocessandtranslations trategies.Tuebingen: Guten Narr.

Leppihalme, R. (1997). Culture bumps: an empirical approach to the translation of allusions. Clevedon: Multilingual Matters.

Moleong, M.A, L.J., Dr. (2000). Metodologi Penelitian Kualitatif
Bandung: Remaja Rosda Karya

Nazir, M. (1983). Metode Penelitian. Jakarta: Galia

Newmark, P. (1984). Approaches to Translation. Pergamon Press

Newmark,Peter.1988.ATextbookofTran slation.New York: Prentice Hall International.

Nida, Eugene A. and Charles R. Taber. 1982. The Theory and Practice of Translation: Netherlands: Leiden.

Nida,E.A. (1964). Towards a science of translation, with special reference to principles and procedures involved in Bible translating. Leiden: Brill.

Richards,etal(1985). Longman dictionary of applied linguistics. UK: Longman

Robinson, Douglas. 2005. Becoming a Translator. Yogyakarta: Pustaka Pelajar.

Seguinot, C. (1989). The translation process. Toronto: H.G. Publications.

Strauss, Anselm\& Corbin, Juliet.(1990).Basicof Qualitative Research:

Venuti, L. (1998). Strategies of translation. In M. Baker (Ed.), Encyclopedia of translation studies(pp. 240-244). London and New York: Routledge.

Walter, Elizabeth. (ed). 2008. Cambridge Advanced Learners' Dictionary ThirdEdition. (CD-ROM). Cambridge: Cambridge University Press.

Zhongying, F. (1994). An applied theory of translation. Beijing: Foreign Languages Teaching \& Research Press. 